\title{
Global Changes in Gene Expression in Sinorhizobium meliloti 1021 under Microoxic and Symbiotic Conditions
}

\author{
Anke Becker, ${ }^{1}$ Hélène Bergès, ${ }^{4}$ Elizaveta Krol, ${ }^{1,2}$ Claude Bruand, ${ }^{4}$ Silvia Rüberg, ${ }^{2}$ Delphine Capela, ${ }^{4}$ \\ Emmanuelle Lauber, ${ }^{4}$ Eliane Meilhoc, ${ }^{4}$ Frédéric Ampe, ${ }^{4}$ Frans J. de Bruijn, ${ }^{4}$ Joëlle Fourment, ${ }^{4}$ \\ Anne Francez-Charlot, ${ }^{4}$ Daniel Kahn, ${ }^{4}$ Helge Küster, ${ }^{2,3}$ Carine Liebe, ${ }^{4}$ Alfred Pühler, ${ }^{2}$ Stefan Weidner, ${ }^{2}$ \\ and Jacques Batut ${ }^{4}$ \\ ${ }^{1}$ Institut für Genomforschung, Centrum für Biotechnologie, Universität Bielefeld, Postfach 100131, D-33501 Bielefeld, \\ Germany; ${ }^{2}$ Lehrstuhl für Genetik, Fakultät für Biologie, Universität Bielefeld, Postfach 100131, D-33501 Bielefeld, Germany; \\ ${ }^{3}$ International NRW Graduate School in Bioinformatics and Genome Research, Universität Bielefeld, Postfach 100131, D- \\ 33501 Bielefeld, Germany; ${ }^{4}$ Laboratoire des Interactions Plantes-Microorganismes, UMR INRA 441-CNRS 2594, BP27- \\ 31326 Castanet-Tolosan cedex, France
}

Submitted 7 August 2003. Accepted 7 October 2003.

\begin{abstract}
Sinorhizobium meliloti is an $\alpha$-proteobacterium that alternates between a free-living phase in bulk soil or in the rhizosphere of plants and a symbiotic phase within the host plant cells, where the bacteria ultimately differentiate into nitrogen-fixing organelle-like cells, called bacteroids. As a step toward understanding the physiology of $S$. meliloti in its free-living and symbiotic forms and the transition between the two, gene expression profiles were determined under two sets of biological conditions: growth under oxic versus microoxic conditions, and in free-living versus symbiotic state. Data acquisition was based on both macro- and microarrays. Transcriptome profiles highlighted a profound modification of gene expression during bacteroid differentiation, with $16 \%$ of genes being altered. The data are consistent with an overall slow down of bacteroid metabolism during adaptation to symbiotic life and acquisition of nitrogen fixation capability. A large number of genes of unknown function, including potential regulators, that may play a role in symbiosis were identified. Transcriptome profiling in response to oxygen limitation indicated that up to $5 \%$ of the genes were oxygen regulated. However, the microoxic and bacteroid transcriptomes only partially overlap, implying that oxygen contributes to a limited extent to the control of symbiotic gene expression.
\end{abstract}

Additional keywords: macroarray, root nodule.

Bacteria of the family Rhizobiaceae can live either as freeliving bacteria in the soil and rhizosphere or as nitrogen-fixing endosymbionts inside root-nodule cells of plants belonging to the family Leguminosae. The initiation of the rhizobia-legume symbiosis is a highly specific and complex developmental process, in which both partners undergo differentiation in a concerted way. In the early stages of the interaction, flavonoids in the root exudates induce the production of Nod factors by the bacteria which, in turn, trigger a developmental program leading to the formation of nodules (Long 2001; Spaink 2000). The bacteria infect the nodule through infection threads

Corresponding author: A. Becker; Telephone: +49 521 106-4824; Fax: +49 521 106-5626; E-mail: Anke.Becker@Genetik.Uni-Bielefeld.DE and colonize the cytoplasm of plant cells in an endocytic-like process. Once inside the plant cells, the bacteria differentiate into nitrogen-fixing bacteroids (Oke and Long 1999a). The stages of bacteroid development have been described at an ultrastructural level for several Rhizobium spp. (Paau et al. 1980; Vasse et al. 1990; Werner and Mörschel 1978).

Differentiation from free-living bacteria into bacteroids appears to involve an alteration of cell fate. Nitrogen-fixing bacteroids are nondividing cells that have adapted their metabolism to nitrogen fixation and life inside the plant cell (Day et al. 2001; Oke and Long 1999a). Whether bacteroids constitute terminally differentiated cells or whether they are able to redifferentiate when they are released from a nodule still remains an unanswered question. Bacteroids surrounded by a plant-derived peribacteroid membrane can be regarded as organelle-like structures, designated symbiosomes. These symbiotic organelles constitute the fundamental cellular unit that carries out nitrogen fixation in root nodules. Sinorhizobium meliloti induces nodules of an indeterminate type on plants of the genera Medicago, Melilotus, and Trigonella.

The different conditions rhizobia face in the free-living state and as nitrogen-fixing endosymbionts inside the plant cell not only are reflected in the expression of a number of bacteroidspecific genes that have been reported over the last two decades (Oke and Long 1999a,b), but also result in differences in protein patterns (Djordjevic et al. 2003; Natera et al. 2000). In particular, oxygen limitation appears to be a key factor driving expression of nitrogen-fixation genes inside root nodules (Soupène et al. 1995). Although rhizobia inhabiting a root nodule have been studied extensively, we still lack a global view of the manner in which gene expression affects both the infection and differentiation processes, as well as the specific properties and maintenance of the bacteroid state.

The basis upon which we are able to study rhizobia has changed due to the availability of complete $S$. meliloti genomic sequences that allow the study of gene expression on a global scale. DNA macro- and microarrays represent ideal tools for global analyses of gene expression at the level of transcription (Becker and de Bruijn, in press; Lockhard and Winzeler 2000; Rhodius et al. 2002). Perret and associates (1999) first reported the complete sequence of the symbiotic plasmid of Rhizobium sp. NGR234 and analyses of transcripts 
derived from this plasmid in the symbiosis. This study demonstrated that such an approach improves our understanding of regulatory mechanisms in the nodule symbiosis. The availability of the complete genome sequence of $S$. meliloti 1021 (Barnett et al. 2001a; Capela et al. 2001; Finan et al. 2001; Galibert et al. 2001) has led to the development of pilot macroarrays for 214 and 34 S. meliloti genes which were analyzed under a variety of symbiotic and nonsymbiotic conditions (Ampe et al. 2003; Bergès et al. 2003).

In this study, we report on expression profiling of all currently predicted 6,207 protein-coding genes of $S$. meliloti 1021 using macro- and microarrays (Becker and de Bruijn, in press; Galibert et al. 2001). Transcript levels of these genes were monitored under oxic and microoxic conditions, as well as in Medicago sativa nodule bacteria enriched for bacteroids to identify networks of genes differentially regulated on the transcriptional level under the conditions studied. Our wholegenome transcriptomics approach identified numerous $S$. meliloti genes that, so far, were not described as being induced or repressed in microoxic and endosymbiotic conditions, and advances our understanding of the nitrogen-fixing endosymbiosis.

\section{RESULTS AND DISCUSSION}

\section{Overall comparison}

of macro- and microarray performances.

Microarrays representing all currently predicted 6,207 protein-coding genes and macroarrays containing 6,063 polymerase chain reaction (PCR) fragments accounting for $97.7 \%$ of the predicted protein-coding genes were used for systematic genome-wide gene expression analysis of S. meliloti 1021. The microarrays consist of 6,046 internal open reading frame (ORF)-specific DNA fragments of 80 to 350 bp and 16170 mer oligonucleotides (Rüberg et al. 2003). The former were generated by PCR amplification using ORF-specific primers carrying standard primer sequences at their $5^{\prime}$ ends. Reamplification using standard primers directed against $5^{\prime}$ extensions of the ORF-specific primers was carried out to generate PCR fragment sets for the production of microarrays (Rüberg et al. 2003) and macroarrays.

In order to compare expression profiles in S. meliloti, parallel hybridizations using identical RNA samples were performed with both types of arrays. Three comparisons of transcript levels were made: i) cells cultured in tryptone-yeast (TY) versus Vincent minimal medium (VMM), ii) cells cultured in microoxic versus oxic conditions, and iii) nodule bacteria enriched for bacteroids versus free-living bacteria cultured in VMM.

To assess the reproducibility of labeling and hybridization procedures, a first series of macroarray and microarray hy- bridizations was carried out using ${ }^{33} \mathrm{P}$ - and Cy5/Cy3-labeled cDNAs generated from identical RNA samples derived from $S$. meliloti cells cultured in TY medium. The results from these experiments showed that $M$ values ( $\log _{2}$ values of the ratio of intensities) $\geq 1.00$ or $\leq-1.00$ and $M$ values $\geq 0.80$ or $\leq-0.80$ pointed to significantly different RNA levels in the microarray

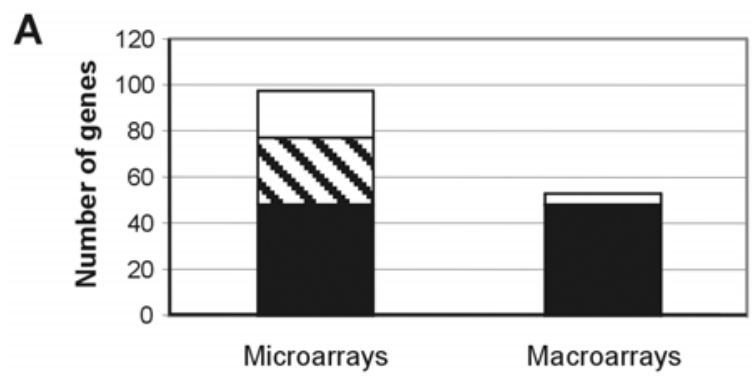

B

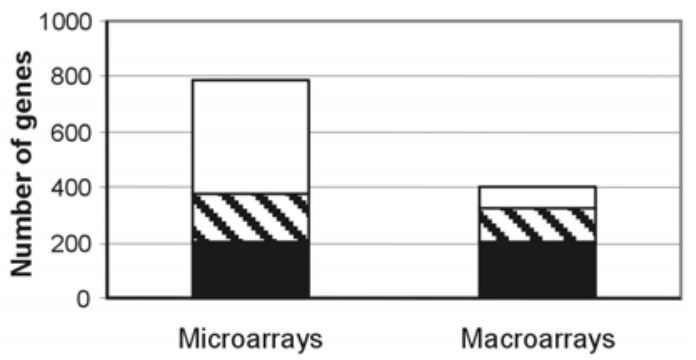

C

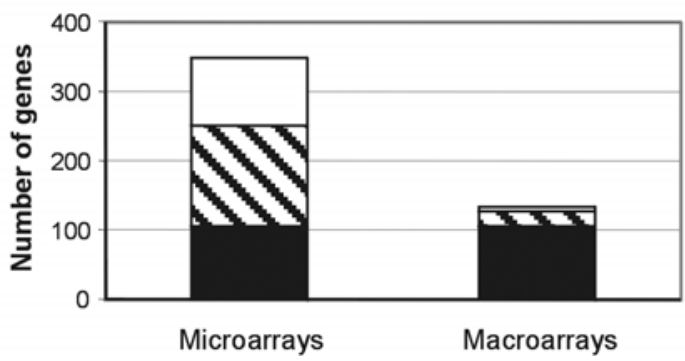

Fig. 1. Number of genes found differentially expressed in A, cells grown in tryptone yeast versus Vincent minimal medium (VMM) media, B, bacteroids versus cells cultivated in oxic VMM, and $\mathbf{C}$, cells grown under microoxic versus oxic conditions. Black boxes $=$ common genes found with both micro- and macroarrays and lined boxes = differentially expressed genes identified solely in micro- or macroarrays but supported by one of the following criteria: i) genes found in a putative operon with or in close proximity to another differentially expressed gene and ii) genes known to be differentially expressed in the experimental condition. White box = differentially expressed genes not supported by one of these criteria.

Table 1. Transcript levels of genes detected as differential by arrays and real-time reverse-transcriptase polymerase chain reaction (RT-PCR) experiments in cells cultured in tryptone yeast rich and in Vincent minimal medium

\begin{tabular}{|c|c|c|c|c|}
\hline Gene & Gene product description & $\begin{array}{c}M \text { value } \\
\text { microarray }^{\text {a }}\end{array}$ & $\begin{array}{c}M \text { value } \\
\text { macroarray }^{b}\end{array}$ & $\begin{array}{c}\log _{2} \text { ratio real- } \\
\text { time PCR }\end{array}$ \\
\hline smc02641 & RkpK UDP-glucose 6-dehydrogenase protein & -0.34 & -0.32 & $0.00^{\mathrm{d}}$ \\
\hline smc00568 & RpsF putative $30 \mathrm{~S}$ ribosomal protein S6 & -0.47 & -0.26 & $0.00^{\mathrm{d}}$ \\
\hline smc01852 & PfK probable pyrophosphate-fructose 6-phosphate 1-phosphotransferase protein & -0.04 & -0.16 & $0.00^{\mathrm{d}}$ \\
\hline smc00324 & Pnp probable polyribonucleotide nucleotidyltransferase protein & -0.17 & -0.22 & $0.00^{\mathrm{d}}$ \\
\hline smc02509 & SitA putative iron-binding periplasmic $\mathrm{ABC}$ transporter protein & 3.09 & 2.32 & 5.83 \\
\hline smc02507 & SitC putative iron transport system membrane $\mathrm{ABC}$ transporter protein & 1.01 & 1.79 & 5.84 \\
\hline smc04383 & conserved hypothetical protein & 2.79 & 1.13 & 6.69 \\
\hline sma2408 & RhbE Rhizobactin siderophore biosynthesis protein & -4.02 & -2.05 & -9.42 \\
\hline $\operatorname{sma} 2414$ & RhtA Rhizobactin receptor precursor & -4.16 & -3.10 & -8.48 \\
\hline sma2412 & RhrA transcriptional activator & -3.21 & -0.86 & -7.86 \\
\hline
\end{tabular}

\footnotetext{
a Average $M$ value calculated from microarray analysis.

b Average $M$ value calculated from macroarray analysis.

c Average $\log _{2}$ ratio calculated from real-time PCR analysis.

${ }^{\mathrm{d}}$ Set to 0.00 , because these genes were used for normalization.
} 
(Rüberg et al. 2003) and macroarray hybridizations, respectively. In the rest of this study, we considered as differentially expressed only genes showing the corresponding $M$ values and $P$ values $\leq 0.05$ according to $t$ statistics (Dudoit et al. 2002). The RNA concentrations of six genes that were identified as differentially expressed in TY versus VMM cultures by the array experiments were quantified by real-time reverse transcriptase (RT)-PCR. In all cases, the differential RNA level was confirmed, although ratios determined by real-time RT-PCR were found to be higher than ratios revealed by array experiments (Table 1).

The number of differentially expressed genes identified by the two techniques is represented in Figure 1. Very strikingly, twice as many potentially differentially expressed genes were detected using microarrays than macroarrays. Most of the genes identified using macroarrays mainly correspond to highly expressed genes and also were found using microarrays, whereas low-expressed genes were predominantly detected by microarrays. Thus, in our experiments, the macroarrays turned out to be less sensitive than microarrays.

A detailed analysis of differentially expressed genes supported the notion that a majority of these genes were likely to be true positives. The criteria we used for this analysis were: i) genes found to be differentially expressed by both micro- and

A

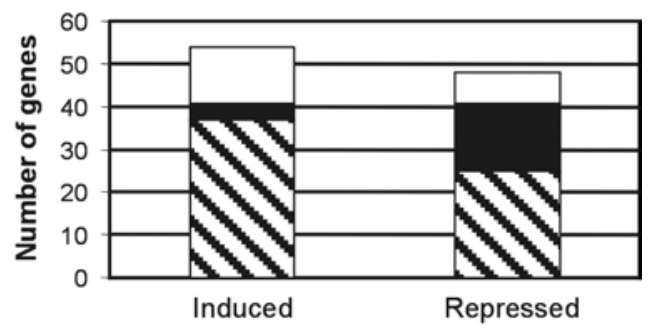

B

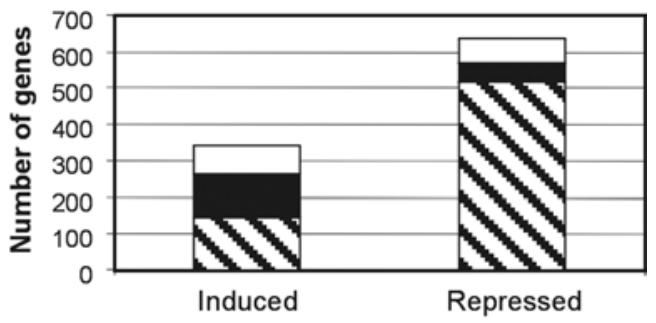

C

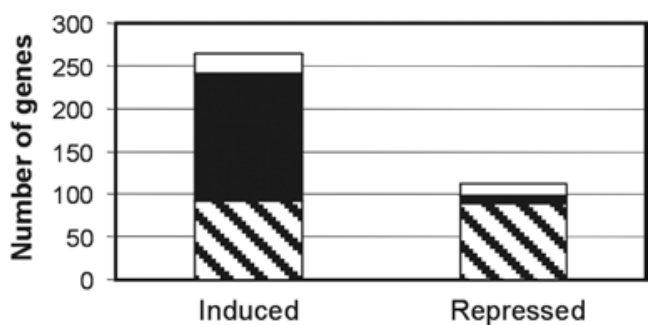

W chromosome $\square$ pSymA $\square$ pSymB

Fig. 2. Replicon assignment of induced and repressed genes under A, tryptone yeast cultures versus Vincent minimal medium (VMM) cultures, $\mathbf{B}$, bacteroids versus VMM-cultured cells, and $\mathbf{C}$, microoxic versus oxic conditions. Lined boxes $=$ chromosomal genes, black boxes $=$ genes on $\mathrm{pSymA}$, and white boxes $=$ genes on $\mathrm{pSymB}$. macroarrays, ii) genes found in a putative operon with or in close proximity to another differentially expressed gene, and iii) genes known to be differentially expressed in the condition tested (Fig. 1). The most striking results found by microarrays, macroarrays, or both methods are presented below. Two issues have to be considered for the interpretation of these expression data. Expression values are determined as relative ratios of expression of an experiment and a reference condition; therefore, the choice of the reference has implications on the data obtained. Thus, the status of a gene being classified as repressed or induced depends on the expression of this gene under both conditions. Moreover, repression cannot be equalized with the absence of the encoded gene product, but should be interpreted as a reduced rate of transcription of these genes.

\section{Gene expression patterns in free-living bacteria.}

In an initial experiment, we compared transcript profiles of S. meliloti 1021 cells cultured in TY and VMM media. Only a low number of genes was found as differentially expressed: 54 genes were induced in TY and 48 genes were induced in VMM. Whereas most differentially expressed genes from pSymB and the chromosome were induced in VMM, those from pSymA were mainly induced in TY (Fig. 2).

Surprisingly, only one gene involved in a biosynthetic pathway (cysD) was induced in VMM, suggesting that TY and VMM are media of equivalent richness. The main class of genes differentially expressed was represented by transporters $(n=29)$. Along with genes involved in transport of amino acids and carbohydrates, a large set of genes $(n=23)$ involved in iron uptake were found to be differentially expressed. Genes involved in synthesis and uptake of the siderophore rhizobactin (rhrA, rhbABCDEF, rhtA, and sma2339) (Lynch et al. 2001) as well as genes probably involved in the uptake of a heme compound ( $h m u S$ and $h m u T$ ) were induced in VMM cultures. Other genes related to iron uptake that were induced in VMM cultures were $f h u A 2$ and smc02726, coding for putative iron receptor outer membrane proteins; and sma1746, $s m b 21432$, smc00784, and smc01659. exbB and exbD, encoding components of the Ton complex that might be associated to siderophore-type transporter systems, also were induced in

Table 2. Genes encoding hypothetical proteins induced more than 5.0fold in bacteroids compared with bacteria cultured in Vincent minimal medium as determined by microarray hybridizations

\begin{tabular}{lc}
\hline Gene accession number & $\boldsymbol{M}$ value \\
\hline sma2131 & 5.73 \\
smc00282 & 5.48 \\
smb21444 & 4.72 \\
sma0835 & 4.67 \\
smc02505 & 3.88 \\
sma0833 & 3.61 \\
sma2034 & 3.39 \\
sma0872 & 3.34 \\
smc03789 01271 & 3.23 \\
sma0914 & 3.21 \\
sma0180 & 3.17 \\
smc02656 & 3.08 \\
sma1554 & 3.04 \\
sma0596 & 3.02 \\
smc00354 & 2.95 \\
sma0565 03901 & 2.90 \\
sma0763 & 2.83 \\
smc00498 & 2.79 \\
smb20042 & 2.73 \\
sma1299 & 2.61 \\
sma0543 & 2.60 \\
& 2.49 \\
& 2.34 \\
& 2.32 \\
\hline
\end{tabular}


cells cultured in VMM. In contrast, genes encoding a putative metal-type iron and manganese transporter system (sitABCD) (Claverys 2001; Platero et al. 2003) were repressed in VMM cultures. The fact that VMM medium contains $\mathrm{FeCl}_{3}$ as an iron source, whereas TY medium probably contains a complex mixture of different iron sources, could explain the pronounced expression of genes related to siderophore biosynthesis and transport systems in VMM medium. In the following experiments, free-living bacteria were grown in VMM as reference.

\section{Gene expression patterns in bacteroids compared with free-living bacteria.}

As mentioned above, differentiation of free-living cells into bacteroids involves a number of structural and metabolic changes that should be reflected in comprehensive alterations of gene expression patterns. To study this process, RNA profiles of nodule bacteria that mainly consisted of bacteroids (referred to as bacteroids, discussed below) and cells cultured in VMM under oxic conditions were compared. Bacteroids were obtained from $M$. sativa nodules.

A total of 982 genes (i.e., $16 \%$ of the $S$. meliloti genes) displaying different RNA levels were identified. Transcripts derived from 342 genes were found to be more frequent, whereas transcripts of 640 genes were less frequent in the bacteroids versus the VMM culture. The high number of differentially expressed genes indicates that the bacterial life style undergoes drastic changes in the bacteroid state. The proportion of genes from the chromosome $\mathrm{pSymA}$ and $\mathrm{pSymB}$ displaying higher
RNA levels in the bacteroids roughly matched the proportion of genes on the three replicons. In contrast, repressed genes more often were chromosomal (Fig. 2).

Interestingly, 167 genes induced in symbiosis, including 24 genes induced more than fivefold (Table 2), were of unknown function. A total of 71 regulatory genes were differentially expressed, among which 38 were induced or repressed more than threefold (Table 3). Gene annotation of 14 of these strongly induced regulatory genes did not reveal any hint about their function. Deciphering the functions of other differentially expressed genes in bacteroids provided clues to understand the modifications in the metabolism and physiology of S. meliloti in the symbiotic state.

\section{Housekeeping functions.}

A down regulation of de novo purine biosynthesis genes (prsA, purQ, purC, guaB, adk, and $n d k$ ) and numerous genes involved in DNA metabolism (dnaA, repB3, dnaN, parE, parC, $s s b$, $i h f B$, and $\operatorname{him} A$ ) was observed in the bacteroids. Interestingly, expression of some genes involved in DNA repair (priA, polA, and alkB) increased in symbiosis. In contrast, expression of mutS, a DNA mismatch repair protein-encoding gene, was repressed. RNA metabolism also was found to be reduced, because rpoA, rрoB, rpoZ, greA, nusA, and nusG genes encoding RNA polymerases and transcription elongation and termination factors were expressed at a lower level in the bacteroids than in VMM-cultured bacteria. The expression of two sigma factor-encoding genes, $r p o E 1$ and $\operatorname{sig} A$, the major sigma factor in $S$. meliloti, was reduced in the bacter-

Table 3. Regulatory genes induced or repressed more than 3.0-fold in bacteroids as compared to bacteria cultured in Vincent minimal medium based on microarray hybridizations

\begin{tabular}{|c|c|c|}
\hline Gene accession number & Annotation of gene product & $M$ value \\
\hline smc01664 & Putative transcription regulator protein & 3.85 \\
\hline $\operatorname{smb20586}$ & Putative transcriptional regulator, IclR family protein & 3.22 \\
\hline sma0762 & FixK2 transcription regulator & 3.20 \\
\hline smc04143 & Putative transcription regulator protein & 3.12 \\
\hline sma0113 & Putative sensory transduction histidine kinase & 3.08 \\
\hline smb20215 & Putative transcriptional regulator protein & 3.02 \\
\hline sma1225 & FixK1 transcriptional activator & 2.90 \\
\hline sma0281 & Putative regulator, MerR family & 2.84 \\
\hline smb20715 & Putative transcriptional regulator, LysR family protein & 2.67 \\
\hline smc01630 & Putative transcription regulator protein & 2.66 \\
\hline smc00241 & Putative transcription regulator protein & 2.38 \\
\hline smc03060 & AglR putative transcription regulator protein & 2.19 \\
\hline sma0840 & NodD3 transcriptional regulator & 2.11 \\
\hline smc00370 & Putative transcription regulator protein & 2.10 \\
\hline smb20055 & Putative transcriptional regulator protein & 1.85 \\
\hline smb20102 & AcoR putative acetoin catabolism regulatory protein & 1.62 \\
\hline sma2303 & Putative ROK family transcriptional regulator & 1.59 \\
\hline$s m b 20425$ & Putative transcriptional regulator protein & 1.59 \\
\hline smc03123 & Putative transcriptional regulator protein & 1.57 \\
\hline smc00720 & Putative 2-component receiver domain protein & -1.58 \\
\hline smc02140 & PhoB phosphate regulon transcriptional regulatory protein & -1.58 \\
\hline smc02826 & Putative transcription regulator protein & -1.64 \\
\hline smc01048 & NrfA probable RNA binding protein & -1.80 \\
\hline smc00943 & WrbA1 putative TRP repressor binding protein homologue & -1.90 \\
\hline smc03006 & CheY1 chemotaxis regulator protein & -1.94 \\
\hline $\operatorname{smb21117}$ & Putative transcriptional regulator protein & -1.98 \\
\hline smc01585 & CspA3 putative cold shock transcription regulator protein & -2.07 \\
\hline smc01371 & CelR1 putative 2-component receiver domain protein & -2.12 \\
\hline$s m b 20935$ & ExsI putative transcriptional regulator protein & -2.15 \\
\hline smc00058 & MucR transcription regulator protein & -2.19 \\
\hline sma0181 & Probable CspA5 cold shock protein transcriptional regulator & -2.24 \\
\hline sma0126 & Putative cold shock protein & -2.54 \\
\hline sma1586 & SyrB2 transcriptional regulator & -2.77 \\
\hline sma0738 & Probable CspA6 cold shock protein transcriptional regulator & -3.01 \\
\hline sma0806 & Probable SyrB-like regulator & -3.13 \\
\hline smc03050 & FlaF putative flagellin synthesis regulator protein & -3.19 \\
\hline smc01428 & CspA2 probable cold shock transcription regulator protein & -3.22 \\
\hline $\operatorname{sma2412}$ & RhrA transcriptional activator & -3.44 \\
\hline
\end{tabular}


oids. None of the other genes encoding putative sigma factors were found to be transcriptionally induced in symbiosis. The translation machinery was largely reduced in the nodule bacteria, because 54 ribosomal protein-encoding genes, as well as nine genes required for translation initiation, elongation, and termination (infA, infB, infC, efp, tufA, tufB, fusAl, $\operatorname{prf} B$, and $r r f$ ), were found to be repressed in nodules. Seven genes involved in the synthesis of amino-acyl tRNAs ( $g l t X$, gatBAC, alaS, aspS, and proS) also were repressed in the bacteroids. In contrast, $\arg S$ and miaA, encoding an arginyltRNA synthetase and a tRNA $\Delta 2$-isopentenylpyrophosphate transferase protein, were induced. The genes encoding RNAseE, RNAseD, and RNAseP were repressed, implying that processing of rRNAs and tRNA precursors, as well as degradation of mRNA, are reduced in the bacteroid state.

Finally, expression of both $f t s Z 1$ and $f t s Z 2$ cell division genes were reduced in the bacteroids, as well as that of $c t r A$, encoding a protein homologous to the response regulator involved in the control of cell cycle progression in Caulobacter crescentus (Barnett et al. 2001b).

Altogether, the high number of genes related to housekeeping functions that appeared repressed in bacteroids are in agreement with the slowed-down general metabolism of bacteroids, as well as their nondividing status. Repression might be interpreted as a reduced requirement for a high rate of transcription of these genes in the nondividing cells compared with the dividing cells harvested in the late logarithmic growth phase from VMM cultures.

\section{Adaptation.}

In all, 25 genes related to motility and chemotaxis were repressed in the bacteroids, and 23 of these genes are located in the motility and chemotaxis gene cluster on the chromosome (Sourjik et al. 1998). Furthermore, two genes related to chemotaxis ( $m c p X$ and cheW3) that are unlinked to the motility and chemotaxis gene cluster displayed a lower RNA level in these bacteria.

Drastic changes in expression of genes encoding transport systems were observed. In fact, 114 genes related to transport processes displayed different RNA concentrations in the bacteroids. Many of these genes have an as yet unknown substrate. Nine genes related to uptake and utilization of phosphorus compounds (smc02146, pstCAB, phoU, and phoCDET) were repressed. However, mutants in the phoCDET-encoded phosphate transport system previously were shown to form root nodules that fail to fix nitrogen (Bardin et al. 1996), thus indicating that these genes are required at some stage of the symbiotic interaction and that repression may not have resulted in the complete absence of the corresponding transcripts. This also is supported by the detection of PhoD in nodule bacteria (Djordjevic et al. 2003). Fourteen genes related to iron uptake were repressed in the bacteroid preparation compared with VMM-cultured cells. Among these genes were the bacterioferritin gene $b f r$, and $r h b A B C D E$, rhtA, and sma2339 involved in the synthesis and uptake of the siderophore rhizobactin, a high-affinity iron chelator, as well as $r h r A$ encoding a transcriptional activator of these genes (Lynch et al. 2001). $h m u S$, involved in uptake of a heme compound, as well as fhuA2 and smc02726, encoding putative iron receptor outer membrane proteins, also were repressed. fhuA2 forms a putative operon with $s m c 01658$ and $s m c 01659$, probably encoding cation transport proteins. The latter two genes also were found to be repressed. Consistent with the association of siderophore-type transporter systems to the Ton complex, $e x b B$ - and exbD-encoding components of this complex displayed a lower RNA level in the bacteroids. $a f u A$, the first gene of the $a f u A B C$ operon, also was among the repressed genes. This operon encodes a ferric-type $\mathrm{ABC}$ transporter and was first characterized in Actinobacillus pleuropneumoniae (Chin et al. 1996). Other genes related to iron uptake that were found to be repressed were smb21432 and smb21430, probably belonging to the same operon, and smc00784. Thus, no gene suggested to be involved in iron uptake was found to be induced in the bacteroids. However, repression does not indicate that these genes are not expressed in the nodule bacteria. This is supported by the detection of proteins encoded by five of these genes (smb21432, smc02726, smc04317, afuA, and fhuA2) in nodule bacteria (Djordjevic et al. 2003).

The katA gene, encoding a monofunctional catalase, and $o x y R$, probably encoding a transcriptional activator of katA (Hérouart et al. 1996), were induced in the bacteroids. The induction of $o x y R$ and katA is in agreement with the expression pattern of katA in bacteroids reported by Jamet and associates (2003) and the presence of the KatA protein in nodule bacteria (Djordjevic et al. 2003). This supports the proposed role for katA in responding to oxidative stress in the bacteroid state. Another gene induced in the bacteroids which might play a role in this respect was sma2031, coding for a putative chloroperoxidase. The superoxide dismutase encoding gene sodA appeared to be repressed, although disruption of the $\operatorname{sodA}$ gene previously was shown to affect symbiotic efficiency of $S$. meliloti in alfalfa (Santos et al. 2000). Repression may not have resulted in the absence of the sodA gene product in the nodule, as is suggested by the identification of this protein in nodule bacteria by Djordjevic and associates (2003).

Seven genes encoding putative cold-shock transcriptional regulators were repressed, whereas three genes, probably encoding heat-shock proteins, were induced in the bacteroids. Among the induced genes encoding heat-shock proteins was the $s m b 21295$ gene that was identified as putatively bacteroid specific by proteomic studies (Djordjevic et al. 2003).

\section{Energy and central intermediary metabolism.}

Genes encoding most of the enzymes of glycolysis ( $p g i$, $f b a B, c b b A 2, g a p, g p m A$, and eno) were repressed in the bacteroids, which was expected because the main carbon source in this compartment is dicarboxylic acids (Lodwig and Poole 2003). The $d c t A$ gene, encoding the dicarboxylate transporter, was repressed in the bacteroids as expected given the high concentration of succinate $(10 \mathrm{mM})$, an inducer of $\operatorname{dct} A$, used as carbon source in the reference VMM medium. In addition, iolB, encoding a protein involved in the catabolism of myoinositol, was induced, suggesting that this compound may be used as a carbon source in bacteroids.

Although the tricarboxylic acid (TCA) cycle is known to be active in bacteroids because of the input of dicarboxylates, genes encoding most enzymes of the TCA cycle (icd, sucCDAB, $s d h A B, s d h C$, fum $C$, and $m d h$ ) were repressed. We interpret this as a consequence of the high activity of the TCA cycle in the control bacteria grown in the presence of elevated concentrations of succinate. Genes encoding enzymes involved in the anaplerotic pathways required to generate acetyl-CoA (tme, $p c k A$, and $p d h A b B)$ were repressed as well in the bacteroids. This was expected for tme (Driscoll and Finan 1997) but is in disagreement to a previous study of $p d h$ genes (Cabanes et al. 2000). gabD3, a gene encoding a succinic semialdehyde dehydrogenase, was induced in the bacteroids, implying a functional glyoxylate shunt as suggested for Bradyrhizobium japonicum (Green et al. 2000).

Given the low oxygen concentration in the nodule, numerous genes involved in $S$. meliloti aerobic respiration (nuoACEFHIKLMN, $s d h B, f b c F B, c t a C D$, and $c t a G E$ ) were repressed. The main functional terminal oxidase in bacteroids seems to be the $c b b_{3}$ cytochrome oxidase encoded by the 
fixNOQP genes. All three copies of these genes were found to be induced. The symbiotic microaerobic respiratory chain may involve a new quinone oxidoreductase (SMb21290) and cytochrome $c_{552}$ encoded by the $c y c B 1$ gene. The presence of cytochrome $c_{552}$ previously was reported in $B$. japonicum bacteroids but it is not essential for symbiotic nitrogen fixation (Rossbach et al. 1991). Interestingly, the paralogous S. meliloti gene $c y c B 2$ was repressed in the bacteroids, indicating a different regulation of these two genes. As previously shown by Kereszt and associates (1995), we also found that $c y c K$ involved in cytochrome $c$-type biogenesis is expressed in nodules, which is consistent with its requirement for $S$. meliloti symbiotic respiration. Electron transfer usually is coupled to the translocation of protons from the cytoplasm to the periplasm. Arslan and associates (2000) have shown that the $c b b_{3}$ oxidase can act as a proton pump in $B$. japonicum. In aerobic cultures, rhizobia generate ATP by oxidative phosphorylation. In the bacteroids, atpHAG, atpC, and atpIBEF $2 F$ genes encoding ATP synthase were repressed. This observation might be interpreted as a consequence of the high demand for ATP synthase in the fast-growing control bacteria compared with the nondividing bacteroids.

\section{Symbiosis-related functions.}

Genes involved in nitrogen fixation are located mainly in two clusters of the pSymA plasmid of $S$. meliloti (Renalier et al. 1987). The first gene cluster contains the nifHDKE operon and eight adjacent nif and fix genes. All of these genes were strongly induced in the bacteroids together with $f d x N$ and $f d x B$, which also are involved in nitrogen fixation, and sma0833 and sma0835, which encode proteins of unknown function. Both genes of the orf110-nifN operon were strongly induced in the bacteroids as well. Only the chromosomal putative nifS gene was not found to be differentially expressed, although this gene previously was reported to be induced in nodules (Oke and Long 1999b). In agreement with previous results (Batut et al. 1989; Cosseau et al. 2002), fixK1 and fixK2 as well as fixM were found to be up regulated in the second cluster of fix genes. Expression patterns of the three fixNOPQ operons are described below.

With respect to genes involved in nitrogen assimilation, both $g \ln B$ and $g \ln A$, encoding the PII protein and glutamine synthetase I (GSI), respectively, were repressed in symbiosis as well as another putative glutamine synthetase gene (smc00762). $g \ln E$, which inactivates GSI by post-translational modification, was induced in the bacteroids. Neither the glutamine synthetase II encoding gene $g \ln I I$ nor $g \ln K$ or $a m t B$ were detected as differentially expressed in symbiosis. Consistent with these results, in nodule bacteria $g \ln A, g \ln B$, and $g \ln K$, gene products were not identified and only traces of the GlnII protein were detected in proteomic studies (Djordjevic et al. 2003).

Eighteen differentially expressed genes presumably are involved in transport of amino acids, amines, and peptides: four were induced and all others were repressed. Recently, Lodwig and associates (2003) suggested that an aspartate or glutamate shuttle encoded by two different sets of genes, aap and bra, drives fixed-nitrogen $\left(\mathrm{NH}_{3}\right)$ assimilation in the Rhizobium leguminosarum-pea symbiosis. S. meliloti genes homologous to aap (smc02118 to smc02121) and bra (smc01946 and smc01950) were repressed in the bacteroids. Instead, sma0677, encoding a putative glutamate or aspartate transporter, was induced. Thus, SMa0677 is an additional candidate transport system in $S$. meliloti that may enable uptake or export of glutamate, aspartate, or other amino acids from or to the plant.

Very unexpectedly, 10 genes related to nodulation, including nodA, nodD1 or nodD3, nodN, nodL, nolG, nfeD, and noeA, were induced in the bacteroids. $s y r B$, specifying a transcrip- tional repressor of syrM (Barnett and Long 1997), and the paralogous gene syrB2 (Sharypova et al. 1999) were repressed. SyrM, which encodes an activator of nodD3, was not found to be differentially expressed in the array experiments. In contrast, previous studies have shown that the nod genes were repressed, whereas syrM was induced in bacteroids (Sharma and Signer 1990).

Rhizobial surface polysaccharides such as exopolysaccharides (EPS), capsular polysaccharides (KPS), and lipopolysaccharides (LPS) play a role in promoting the infection of root nodules (Niehaus and Becker 1998). Seventeen genes related to biosynthesis of surface polysaccharides exhibited different RNA levels in the bacteroids and VMM-cultured cells. Among the genes associated to the biosynthesis of LPS, acpXL, lpxD, fabZ, and $\operatorname{lp} x A$ involved in lipidA synthesis were repressed, whereas lps $B$, encoding a glycosyltransferase participating in the biosynthesis of the LPS core (Kanipes et al. 2003), was induced in the bacteroids. $S$. meliloti $\operatorname{lps} B$ mutants fail to effectively colonize M. truncatula and M. sativa nodules (Campbell et al. 2002; Niehaus et al. 1998). Induction of $\operatorname{lps} B$ in bacteroids and the symbiotic phenotype of mutants in this gene suggest that $\operatorname{lps} B$ contributes to structural changes of LPS in bacteroids. Such structural changes were reported for $R$. leguminosarum during bacteroid development (Kannenberg et al. 1998).

A low molecular mass form of succinoglycan promotes infection of root nodules (Niehaus and Becker 1998). Transcript frequencies of three genes ( $m u c R$, exoT, and $s y r A$ ) related to the biosynthesis of succinoglycan were altered. The observed repression of the regulatory $m u c R$ gene and induction of exoT involved in synthesis of low molecular mass succinoglycan may result in a reduction of the overall production of succinoglycan and the predominant synthesis of the low molecular mass form (Bertram-Drogatz et al. 1998; González et al. 1998). syrA, a regulatory gene affecting succinoglycan production (Mulligan and Long 1989), was induced. In contrast to previous studies, a reduced expression of exo $A$, exoP, and exoF in the symbiotic zone of the nodule (Reuber et al. 1991) was not observed in our array experiments. The presence of infecting bacteria in the bacteroid preparation could explain this unexpected expression of nod and exo genes.

KPS can partially replace succinoglycan in symbiosis (Pellock et al. 2000). Three genes related to the biosynthesis of KPS exhibited different RNA levels. $R k p K$, involved in the biosynthesis of KPS and LPS (Kereszt et al. 1998), and $r k p U$ were repressed, whereas rkpI was induced. Furthermore, six genes involved in biosynthesis of as yet unknown polysaccharide structures displayed different RNA levels in the bacteroids and VMM-cultured cells. Three of these genes were repressed (algI, kpsF2, and smc04185) and three were induced (smb21074, smb21078, and exoF3). The role of these genes in the bacteroid state remains to be investigated.

Eight outer membrane and three lipoprotein encoding genes were repressed. Among these genes was ropB1. Repression of rop $B 1$ is in agreement with previous reports of Roest and associates (1995), who reported a strong decrease of the R. leguminosarum RopB protein during symbiosis.

\section{Global changes in gene expression patterns under microoxic and oxic conditions.}

Oxygen limitation is an important environmental factor triggering Rhizobium symbiotic gene expression (Soupène et al. 1995). Therefore, we compared the $S$. meliloti transcriptome under oxic and microoxic conditions. RNAs were purified from cells cultivated in bioreactors in which the oxygen partial pressure $\left(\mathrm{pO}_{2}\right)$ was maintained either at $60 \%$ of saturation by air (approximately $150 \mu \mathrm{M}$ dissolved oxygen) or below the detection limit of the electrodes (less than $1 \mu \mathrm{M}$ dissolved oxy- 
gen). Expression profile analysis highlighted 377 genes regulated by oxygen (i.e., $5 \%$ of total $S$. meliloti genes). Among the differentially expressed genes identified, $70 \%$ (266 genes) were induced in microoxic conditions and 30\% (111 genes) were repressed. The pSymB megaplasmid appeared to carry very few (37) oxygen-regulated genes. The chromosome concentrates $80 \%$ of the repressed genes, whereas most induced genes (136 genes) were found to belong to two large loci on the pSymA megaplasmid (Fig. 3). These two loci span 120 and $140 \mathrm{~kb}$, respectively, and correspond to the fix loci identified previously (Renalier et al. 1987). No repressed gene was identified in these regions.

\section{Contribution of oxygen}

\section{to the regulation of symbiotic gene expression.}

Oxygen limitation is known to play a key role in the regulation of genes involved in nitrogen fixation and bacteroid respiration; therefore, we compared the microoxic and bacteroid transcriptomes. Surprisingly, only 31 genes were found to be induced under both conditions.

Among the genes expressed in the bacteroids that also were under oxygen control were the fixNOQP genes, fixH, fixM, the transcriptional regulators nifA and fixK, the chromosomal genes involved in proline metabolism ( roB2 and smc03253) located downstream of the fixT3 copy, the putative glutamateaspartate shuttle gene sma0677, two other genes encoding components of ABC transport systems (sma1995 and sma0104), and eight hypothetical genes of unknown function.

A large number of genes (311) induced in the bacteroids were not induced under microoxic conditions. This was the case for nif genes, although their expression is oxygen regulated under NifA control. The reason for this may be the much lower free oxygen concentration in nodules $(18 \mathrm{nM})$ (Layzell et al. 1990) compared with microoxic cultures (approximately $1 \mu \mathrm{M}$ ) that allows NifA activity. The proportion of genes solely induced in bacteroids that are under NifA control remains to be determined. However, it is likely that a large number of genes induced in the bacteroids are actually not (or not solely) under oxygen control.

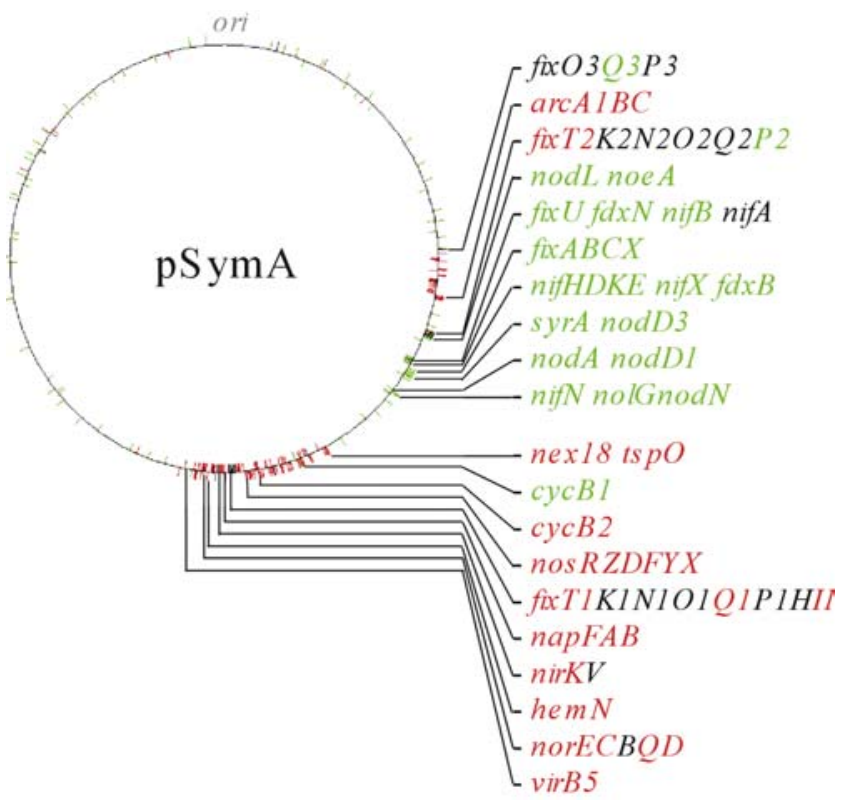

Fig. 3. Position of genes induced in microoxic conditions and in bacteroids on pSymA. Genes induced under microoxic conditions are indicated by red lines. Genes induced in bacteroids are indicated by green lines. Genes induced under both microoxic and symbiotic conditions are indicated by black lines.
Conversely, a number of genes were induced or repressed under microoxic conditions but nevertheless were not differentially regulated in bacteroids. This was true for fixT, the FixL antikinase, and two other new $S$. meliloti terminal oxidases: i) the $q x t A B$ genes resembling a quinol oxidase of Rhodobacter sphaeroides, and ii) cyoABC genes encoding a cytochrome $o$ ubiquinol oxidase. The $c y c B 2$ gene encoding a cytochrome $c_{552}$ was induced under low-oxygen concentration but repressed in symbiosis, whereas its paralogue, $c y c B 1$, was induced in the bacteroids but not in oxygen-limited cultures.

The $t s p O$ gene coding for a regulator of nutrient deprivation induced genes (Davey and de Bruijn 2000) was induced by oxygen limitation, as well as the nex 18 gene belonging to the same locus. nex 18 and $t s p O$ previously were found predominantly expressed in nodules (Oke and Long 1999b), and the Nex 18 protein was detected under various conditions, including nodule bacteria (Djordjevic et al. 2003). Nevertheless, neither nex 18 nor $\operatorname{tsp} O$ were identified as differentially expressed in the bacteroids.

Genes of the denitrification pathway, enabling the complete reduction of nitrate to molecular nitrogen (nap, nir, nor, and nos), were induced under microoxic conditions. S. meliloti previously had been shown to possess denitrifying activities in both free-living and symbiotic forms (O'Hara et al. 1983); therefore, we would have expected the complete pathway to be induced in bacteroids. Instead, only two genes, nirV and norB, were induced in the bacteroids.

Near the putative aspartate-glutamate transporter gene sma0677, which was induced in both oxygen limitation and symbiotic conditions, a probable polyamine transport gene (sma00678) and arginine degradation genes (arcAlBC, sma0680, and sma0682) were found to be specifically induced under microoxic conditions. Arginine is converted into ornithine and carbamoyl phosphate, which serves to generate ammonium and ATP from ADP. The arginine degradation pathway has been studied in Pseudomonas aeruginosa and Rhizobium etli, in which $\operatorname{arc} A B C$ genes also are expressed at low oxygen concentrations (D'Hooghe et al. 1997; Luthi et al. 1986). It previously was shown that $S$. meliloti mutants unable to catabolize ornithine are affected in nodulation efficiency and in competitiveness (Jiménez-Zurdo et al. 1995). However, none of these genes was induced in symbiosis. Hence, a conclusion of these experiments is that many genes that are under oxygen control may undergo a more complex regulation in bacteroids.

Comparison of the bacteroid transcriptome and proteome.

Recently, Djordjevic and associates (2003), using a proteomic approach, reported 439 proteins from S. meliloti 1021 bacteria isolated from either Melilotus alba or Medicago truncatula nodules, and identified 165 of these proteins. Most identified proteins are encoded by genes that we have found highly expressed in microarray experiments (Fig. 4). Most of these genes were not regulated at the transcriptional level under the conditions we tested, because only 13 genes were induced in the bacteroids, among which were nifHDK, fixBC, katA, and $p d x J$, the latter being involved in pyridoxine biosynthesis. Moreover, 55 genes, among which were genes encoding ribosomal proteins, transcription and translation elongation factors, and TCA cycle and pyruvate dehydrogenase PDH complex enzymes, were repressed at the RNA level, confirming that a down regulation does not imply that the corresponding gene product is not produced.

Among the 165 proteins identified by Djordjevic and associates (2003), 27 were putative nodule specific (i.e., were not found in any other condition tested). Of the corresponding genes, 13 were not detected as differentially expressed in our 
array experiments, and only 8 were found induced, including the nifHDK and fixBC genes, as well as genes encoding the small heat-shock protein SMb21295, the ribonuclease SMc02819, and the hypothetical protein SMc03251. Surprisingly, here, six putative nodule-specific proteins correspond to genes repressed in the bacteroids. Among these proteins, some are involved in housekeeping functions, such as the RNA polymerase $\alpha$-chain RpoA, the TCA cycle enzyme SdhA, and the leucine biosynthesis protein LeuB, and are unlikely bacteroid-specific proteins.

The limited overlap between the proteomic and the transcriptomic approaches could be accounted for by the culture conditions of free-living bacteria used as a reference in the two studies. Another difference is the plant partner, because $M$. sativa was used in our transcriptome experiments, whereas Melilotus alba and Medicago truncatula both were used for proteome experiments. Thus, proteomic and transcriptomic analyses performed on the same biological material are needed to evaluate more rigorously the congruency of results obtained by the two approaches.

In addition, more experiments such as quantitative RT-PCR are needed to validate the transcriptome data. We noticed few discrepancies between the results from the whole-genome array studies and the data obtained by the pilot macroarrays by Ampe and associates (2003), concerning in particular $p d h A$, ialA, sitA, and cyaF6 induction in symbiotic bacteria, that need to be solved out.

\section{Conclusions.}

This study demonstrated that genome-wide approaches to monitor gene expression advance our understanding of the versatility of $S$. meliloti to adapt to conditions that are as different as a life in the soil and as an organelle-like endosymbiont inside the plant cell. Although the bacteroid state has been studied extensively for many years and immense knowledge was accumulated, our global view on the way gene expression affects the differentiation process and the maintenance of the bacteroid state is still sketchy. The expression profiling experiments reported here lay the foundation for future studies toward a better understanding of the physiology of these different life styles and the transition from the free-living to the symbiotic state. The low-oxygen and symbiotic transcriptomes described in this study, including numerous genes that, so far, were not identified as being induced under these conditions, represent a valuable data resource.

\section{MATERIALS AND METHODS}

Strains, media, and growth conditions.

S. meliloti wild-type strain 1021 (Meade and Signer 1977) was grown in TY complex medium (Beringer 1974) or VMM (Vincent 1970) at $30^{\circ} \mathrm{C}$. VMM medium was composed of 14.7 $\mathrm{mM} \mathrm{K} \mathrm{HPO}_{4}, 11.5 \mathrm{mM} \mathrm{KH} \mathrm{PO}_{4}, 0.46 \mathrm{mM} \mathrm{CaCl}, 0.037 \mathrm{mM}$ $\mathrm{FeCl}_{3}, 1 \mathrm{mM} \mathrm{MgSO} 4,15.7 \mathrm{mM} \mathrm{NH} \mathrm{NL}_{4}, 10 \mathrm{mM}$ sodium succinate, $4.1 \mu \mathrm{M}$ biotin, $48.5 \mu \mathrm{M} \mathrm{H}_{3} \mathrm{BO}_{3}, 10 \mu \mathrm{M} \mathrm{MnSO}_{4}, 1 \mu \mathrm{M}$ $\mathrm{ZnSO}_{4}, 0.5 \mu \mathrm{M} \mathrm{CuSO}_{4}, 0.27 \mu \mathrm{M} \mathrm{CoCl}_{2}$, and $0.5 \mu \mathrm{M} \mathrm{NaMoO}_{4}$; $\mathrm{pH}$ 7. Cells were cultured in $50 \mathrm{ml}$ of liquid medium in $250-\mathrm{ml}$ Erlenmeyer flasks and shaken at $150 \mathrm{rpm}$ until an optical density at $600 \mathrm{~nm}\left(\mathrm{OD}_{600}\right)$ of 0.8 was reached. RNA prepared from these cultures was used for comparison of gene expression in VMM and TY media.

Cells for comparison of gene expression under oxic and microoxic conditions were cultured in 1 liter of bioreactors (Setric Toulouse, Toulouse, France) in VMM at $30^{\circ} \mathrm{C}$ and $\mathrm{pH}$ 6.8. Oxic cultures were conducted under an oxygen pressure $\left(\mathrm{pO}_{2}\right)$ always greater than $60 \%$ of saturation by air. In mi- crooxic cultures, $\mathrm{pO}_{2}$ initially was kept high $(>60 \%$, as in the aerated cultures) until an $\mathrm{OD}_{600}$ of 0.2 . The reactors then were flushed rapidly with $\mathrm{N}_{2}$ and the $\mathrm{pO}_{2}$ was maintained below the detection limit of the electrodes (apparent $\mathrm{pO}_{2}=0$; (i.e., less than $1 \mu \mathrm{M}$ dissolved oxygen), although a constant input of oxygen was maintained to ensure bacterial growth and energy metabolism.

\section{Cultivation of plants for bacteroid isolation.}

Seed of $M$. sativa cv. Sitel were sterilized and grown in aeroponic tanks as previously described (Gallusci et al. 1991). Plants first were grown in a medium supplemented with $5 \mathrm{mM}$ ammonium nitrate. After 10 days of growth in the presence of nitrogen, the medium was changed to nitrogen-free medium. After two more days, plants were inoculated with $S$. meliloti to promote nodulation. Nodules were harvested 18 to 22 days after inoculation, were immediately frozen in liquid nitrogen, and were stored at $-80^{\circ} \mathrm{C}$ until RNA extraction.

\section{Contents and layout of Sm6k microarrays.}

In this study, the Sm6k microarrays described by Rüberg and associates (2003) were used. Each microarray contains 6,046 PCR fragments and 161 70-mer oligonucleotides as ORF-specific probes, and three alien DNA fragments (Spot Report Alien PCR product \#1, Stratagene 252551; Spot Report Alien PCR product \#2, Stratagene 252552; Spot Report Alien PCR product \#3, Stratagene 252553; Stratagene, La Jolla, CA, U.S.A.) that can serve as probes for spiking controls. Each probe was spotted in triplicate. DNA fragments were generated by two rounds of PCR amplification as described by Rüberg and associates (in press). In the first round, ORFspecific primers carrying H1 (GGTTCCACGTAAGCTTCC), B4 (GCGATTACCCTGTACACC), or M3 (GCCAGTACATC AATTGCC) 5' extensions were used. These primary PCR products were reamplified using these extensions as standard priming sites.

\section{PCR amplifications, and printing and layout of macroarrays.}

For the generation of macroarrays, purified primary PCR products (Rüberg et al. 2003) were reamplified in 100- $\mu$ l reactions using suitable combinations of standard primer $(\mathrm{H} 1$, B4, and M3) pairs and Taq DNA polymerase. The size of the resulting PCR products was evaluated by agarose gel electrophoresis using the software Fragment Analysis (Molecular

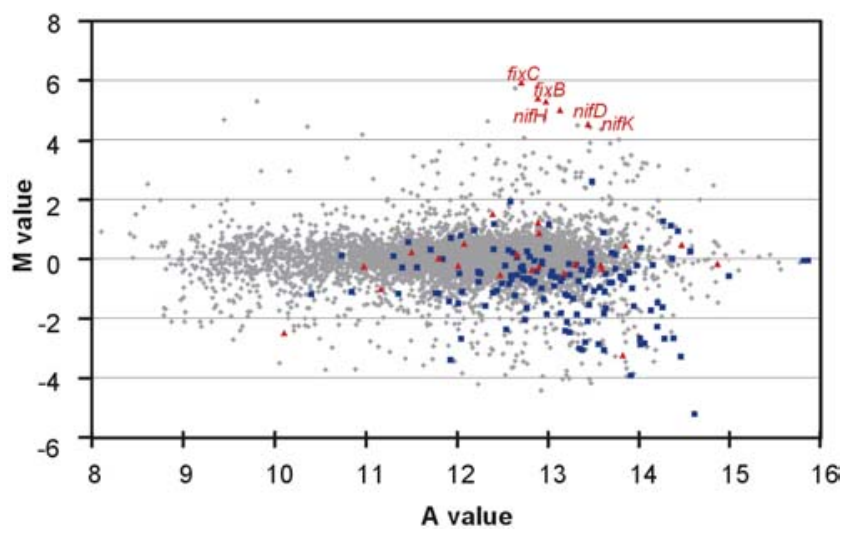

Fig. 4. Scatterplot of $M$ values versus $A$ values obtained for the comparison of bacteroids versus aerated Vincent minimal mediumcultured cells by microarray hybridizations. Blue squares are genes encoding proteins identified in the bacteroid proteome study, and red triangles correspond to genes encoding putative nodule specific proteins (Djordjevic et al. 2003). 
Dynamics, Sunnyvale, CA, U.S.A.). Ninety-six of the PCR products, randomly selected, were sequenced and showed the correct sequences. PCR reactions then were purified using Bio-Gel P-100 (Bio-Rad, Hercules, CA, U.S.A.) in microplaques (Millipore, Bedford, MA, U.S.A.). DNA concentration of the purified PCR products was measured on a Fluoroscan Bio-Tek FL600 (Fisher Scientific Labosi, Elancourt, France) on the basis of their fluorescence in the presence of PicoGreen (Molecular Probes, Leiden, The Netherlands). Purified PCR products were evaporated and resuspended in $5 \mu \mathrm{l}$ of Tris-EDTA buffer (10 mM Tris, 1 mM EDTA, $\mathrm{pH} 7.5)$.

Thus, each macroarray contains 6,063 PCR fragments, which corresponds to $97.7 \%$ of the genome. Each probe was spotted once per macroarray. Five alien DNA fragments were also included (in duplicates), which correspond to five genes from Corynebacterium striatum without homologue in the $S$. meliloti genome, and can serve as probes for spiking controls. PCR fragments (200 to $500 \mathrm{ng} / \mu \mathrm{l}$ ) in $50 \%$ dimethyl sulfoxide were printed onto Immobylon-Ny+ membranes (Millipore) using the MicroGrid II 600 spotter (BioRobotics, Cambridge) equipped with 96 solid pins. DNA was crosslinked to the surface using a UV Stratalinker 2400 (Stratagene).

\section{RNA purification.}

For comparison of gene expression in VMM and TY medium, cells from free-living cultures $\left(50 \mathrm{ml}\right.$ at $\left.\mathrm{OD}_{600}=0.8\right)$ were harvested by centrifugation $\left(10,000 \times g, 1 \mathrm{~min}, 20^{\circ} \mathrm{C}\right)$ and cell pellets were frozen immediately in liquid nitrogen. Total RNA was purified using the RNeasy Mini Kit (Qiagen, Hilden, Germany). Cells were disrupted in RLT buffer provided with the kit in Fast Protein tubes (Q BIOgene, Carlsbad, CA, U.S.A.) using the Ribolyser (Hybaid, Heidelberg, Germany) (30 s, level 6.5) prior to spin column purification according to the RNeasy mini kit RNA purification protocol.

For comparison of gene expression under oxic and microoxic conditions, cells cultured in bioreactors $\left(25 \mathrm{ml}\right.$ at $\left.\mathrm{OD}_{600}=0.5\right)$ were rapidly $(<15 \mathrm{~s})$ harvested by filtration $(0.2-\mu \mathrm{m}$ membranes) and filters were frozen immediately in liquid nitrogen and stored at $-80^{\circ} \mathrm{C}$ until RNA extraction. Total RNA was extracted as previously described (Cabanes et al. 2000).

For preparation of RNA from nodule bacteria, nodules were crushed in liquid nitrogen and bacterial cells were separated from vegetal material by differential centrifugations, as previously described (Cabanes et al. 2000). This fraction contained mainly bacteroids but was contaminated by infecting bacteria. Total RNA from these bacteria was prepared either as described in Cabanes and associates (2000) or by a hot phenol procedure. Briefly, the bacteria were resuspended in a prewarmed $\left(60^{\circ} \mathrm{C}\right)$ mixture of $50 \%$ phenol, $25 \mathrm{mM}$ sodium acetate, $5 \mathrm{mM}$ EDTA, $0.5 \%$ sodium dodecyl sulfate (SDS), $\mathrm{pH}$ 4.7, and incubated at $60^{\circ} \mathrm{C}$ for $5 \mathrm{~min}$. RNA then was extracted with phenol-chloroform and ethanol precipitated. Contaminating DNA was removed from RNA preparations by DNase I using Qiagen columns (clean-up procedure).

\section{Labeling of hybridization probes, hybridization, and image acquisition.}

For each comparison, hybridizations accounting for at least two biological and up to two technical replicates were conducted for both microarray and macroarray experiments.

Microarrays. For validation of the microarray printing process and coupling of DNA probes to the glass slide surface, two microarrays from each printing series were hybridized with Alexa 555-labeled random nonamer oligonucleotides (Molecular Probes). Hybridization was carried out with 150 pmol nonamer oligonucleotides in $5 \times \mathrm{SSC}(1 \times \mathrm{SSC}$ is $0.15 \mathrm{M} \mathrm{NaCl}$ plus $0.015 \mathrm{M}$ sodium citrate), $0.2 \%$ SDS in a final volume of $65 \mu \mathrm{l}$ under a coverslip at $21^{\circ} \mathrm{C}$ for $5 \mathrm{~min}$. Microarrays were washed once in $2 \times \mathrm{SSC}, 0.2 \% \operatorname{SDS}\left(30 \mathrm{~s}, 21^{\circ} \mathrm{C}\right)$ and once in $0.2 \times \operatorname{SSC}\left(20 \mathrm{~s}, 10^{\circ} \mathrm{C}\right)$.

Fluorescent-labeled cDNA was prepared according to De Risi and associates (1997) from 5 to $30 \mu \mathrm{g}$ of total RNA. Prehybridization of microarrays was carried out for $45 \mathrm{~min}$ at $42^{\circ} \mathrm{C}$ in Easyhyb hybridization solution (Roche Diagnostics, Mannheim, Germany) supplemented with sonicated salmon sperm DNA at $5 \mu \mathrm{g} / \mathrm{ml}$. Following prehybridization microarrays were washed in MilliQ water $\left(21^{\circ} \mathrm{C}, 1 \mathrm{~min}\right)$, dunked in ethanol $\left(21^{\circ} \mathrm{C}, 10 \mathrm{~s}\right)$, and centrifuged $\left(185 \times \mathrm{g}, 3 \mathrm{~min}, 20^{\circ} \mathrm{C}\right)$. Hybridization was performed at $42^{\circ} \mathrm{C}$ for $16 \mathrm{~h}$ in Easyhyb hybridization solution (Roche Diagnostics) supplemented with sonicated salmon sperm DNA at $50 \mu \mathrm{g} / \mathrm{ml}$ in a final volume of $65 \mu \mathrm{l}$ under a cover slip. Before applying the hybridization sample to the microarray, it was denatured for $5 \mathrm{~min}$ at $65^{\circ} \mathrm{C}$. Microarrays were washed once in $2 \times \mathrm{SSC}, 0.2 \%$ SDS ( $5 \mathrm{~min}$, $\left.42^{\circ} \mathrm{C}\right)$, twice in $0.2 \times \mathrm{SSC}, 0.1 \% \operatorname{SDS}\left(2 \mathrm{~min}, 21^{\circ} \mathrm{C}\right)$, and twice in $0.2 \times \operatorname{SSC}\left(2 \mathrm{~min}, 21^{\circ} \mathrm{C}\right)$.

Following the washes, slides were dried by centrifugation ( 3 min, $185 \times g, 20^{\circ} \mathrm{C}$ ) and scanned with a pixel size of $10 \mu \mathrm{m}$ using the ScanArray 4000 microarray scanner (Perkin-Elmer, Boston).

Macroarrays. In order to assess the quality of the spotting or the amount of DNA remaining after stripping of the filters, each cDNA hybridization was preceded by a hybridization with the standard oligonucleotides H1, B4, and M3. Oligonucleotides H1, B4, and M3 were labeled at their $5^{\prime}$ end with T4 polynucleotide kinase and $\left[\gamma-{ }^{33} \mathrm{P}\right]$ ATP. ${ }^{33} \mathrm{P}$-labeled cDNA was synthesized by random priming from $10 \mu \mathrm{g}$ of total RNA as described by Ampe and associates (2003). For all hybridizations, nylon filters first were prehybridized in $10 \mathrm{ml}$ of hybridization solution (5× SSC, $5 \times$ Denhardt's solution, sheared salmon sperm at 100 $\mu \mathrm{g} / \mathrm{ml}, 0.5 \% \mathrm{SDS}$ ) either for $2 \mathrm{~h}$ at $38^{\circ} \mathrm{C}$ (for oligonucleotide hybridization) or for $6 \mathrm{~h}$ at $65^{\circ} \mathrm{C}$ (for cDNA hybridization). The labeled probes (oligonucleotides or cDNA) then were added and hybridization was carried out for $17 \mathrm{~h}$ at either $38^{\circ} \mathrm{C}$ (oligonucleotide probe) or $65^{\circ} \mathrm{C}$ (cDNA probe). Following hybridization, each filter was washed twice with $2 \times \mathrm{SSC}$ and $0.5 \%$ SDS for $30 \mathrm{~min}$ at $38^{\circ} \mathrm{C}$ (oligonucleotide probe) or $65^{\circ} \mathrm{C}$ (cDNA probe), followed by two washes with $0.2 \times$ SSC and $0.5 \%$ SDS at $65^{\circ} \mathrm{C}$ for $30 \mathrm{~min}$ each (for the cDNA probe only). The filters

Table 4. Primers used for real-time reverse-transcriptase polymerase chain reaction

\begin{tabular}{|c|c|c|}
\hline Gene & Primer 1 & Primer 2 \\
\hline smc02641, rkpK & CTTGCGGTTGTCGTTGACG & TTCATCAACGAGATTGCCGA \\
\hline smc00568, rpsF & TTCTGCATCATCGCGGAC & ATCAAGAAGAACCGCAAGGCT \\
\hline smc01852, pfk & CCGACCGGATCGAAATCA & TCGTGTGCAGGATGCTGATG \\
\hline smc00324, pnp & GTGGAATCGGAAGCGAAAGA & GGTGATCTTATAGGCGTTGCG \\
\hline smc02509, sitA & AGATCCACAATTACCAGCCGA & AAGGCGACATCCAGGCAT \\
\hline smc02507, sitC & GGCACTGAGACAGAACCTCGT & TTGCGGAACTCGCTCATG \\
\hline smc04383 & AACGCATTTCCGAGGAGC & AAATGAGGTCGAGCCTCAGAA \\
\hline $\operatorname{sma2408,} r h b E$ & TCACAGCAACTTTCGGCGT & AATTCGCTGGAATGCATGAG \\
\hline $\operatorname{sma2414,}$ rhtA & TATCGGCTACCAGATCGACGA & TGACGTTCAACATCGAGCG \\
\hline sma2412,rhrA & CTCGCGGCTGAAGAATTTC & ATGATGGTCGCGCATTTCTA \\
\hline
\end{tabular}


were wrapped in clear plastic wrap and exposed to a Phosphorscreen (Amersham Biosciences, Tokyo) for 16 to $24 \mathrm{~h}$ (oligonucleotides) or 5 days (cDNA). Macroarrays were scanned with a pixel size of $50 \mu \mathrm{m}$ using a Storm apparatus (Molecular Dynamics). After use, membranes were stripped by incubation in $0.1 \%$ SDS at $68^{\circ} \mathrm{C}$ six times for $1 \mathrm{~h}$ (oligo probe) or at $95^{\circ} \mathrm{C}$ four times for $1 \mathrm{~h}$ (cDNA probe). Stripping efficiency was checked by exposure to a Phosphorscreen for 5 days.

\section{Data analysis.}

Mean signal and mean local background intensities were obtained for each spot of the microarray images using the ImaGene 5.0 software for spot detection, image segmentation, and signal quantification (Biodiscovery Inc., Los Angeles). Spots were flagged as "empty" if $R \leq 1.5$ in both channels, where $R=$ (signal mean - background mean)/background standard deviation. The remaining spots were considered for further analysis. The $\log _{2}$ value of the ratio of intensities was calculated for each spot using the formula $M \mathrm{i}=\log 2(R \mathrm{i} / G \mathrm{i}) . R \mathrm{i}=I_{\operatorname{ch} 1(\mathrm{i})}-$ $B g_{\mathrm{ch} 1(\mathrm{i})}$ and $G_{\mathrm{i}}=I_{\mathrm{ch} 2(\mathrm{i})}-B g_{\mathrm{ch} 2(\mathrm{i})}$, where $I_{\mathrm{ch} 1(\mathrm{i})}$ or $I_{\mathrm{ch} 2(\mathrm{i})}$ is the intensity of a spot in channel 1 or channel 2 and $B g_{\text {ch1(i) }}$ or $B g_{\operatorname{ch} 2(i)}$ is the background intensity of a spot in channel 1 or channel ${ }^{\mathrm{i}} 2$, respectively. The mean intensity was calculated for each spot, $A_{\mathrm{i}}=\log _{2}\left(R_{\mathrm{i}} G_{\mathrm{i}}\right)^{0.5}$ (Dudoit et al. 2002). A normalization method based on local regression that account for intensity and spatial dependence in dye biases was applied. Within a print tip group, normalization was performed according to Yang and associates (2002), $M_{\mathrm{i}}=\log _{2}\left(R_{\mathrm{i}} / G_{\mathrm{i}}\right) \rightarrow \log _{2}\left(R_{\mathrm{i}} / G_{\mathrm{i}}\right)-\mathrm{c}_{\mathrm{j}}(A)=$ $\log _{2}\left(R_{\mathrm{i}} /\left[k_{\mathrm{j}}(A) G_{\mathrm{i}}\right]\right)$, where $\mathrm{c}_{\mathrm{j}}(A)$ is the lowest fit to the MA plot for the $j$ th grid only (i.e., for the $j$ th print tip group), $j=1, \ldots$, $J$, and $J$ denotes the number of print tips. A floor value of 20 was introduced before normalization. Genes significantly up or down regulated were identified by $t$ statistics (Dudoit et al. 2002). Genes were regarded as differentially expressed if $P \leq$ 0.05 and $M \geq 1.00$ or $M \leq-1.00$. Normalization and $t$ statistics were carried out using the EMMA 1.0 microarray data analysis software developed at the Bioinformatics Resource Facility (Dondrup et al. 2003).

For analysis of macroarray hybridization experiments, the median signal and median local background intensities were quantified using ImaGene 5.0 (Biodiscovery Inc.). Median intensities were globally normalized by the mean of median signals. Genes significantly up or down regulated were identified by $t$ statistics. Genes were regarded as differentially expressed if $P \leq 0.05$ and $M \geq 0.80$ or $\mathrm{M} \leq-0.80$. Normalization and $t$ statistics were carried out using the GeneSight software (version 3.5; Biodiscovery Inc.).

\section{Real-time PCR.}

Reverse transcription was carried out with $8 \mu \mathrm{g}$ of total RNA using Superscript II reverse transcriptase and random hexamers as primers. After RNA degradation by alkaline hydrolysis and neutralization, cDNAs were purified on Microcon YM-30 columns and redissolved in $50 \mu \mathrm{l}$ of water. This cDNA solution (1 $\mu \mathrm{l})$ was used for real-time RT-PCR using the Qiagen SYBR green PCR Master mix kit (Qiagen) according to the manufacturer's instructions. Every reaction was made in two replicates. Reactions were run on the Opticon real-time PCR cycler (MJ Research, Waltham, MA) and quantification was performed with the Opticon Monitor analysis software, version 1.4. Primers used are listed in Table 4. Gene expression ratios were calculated as the ratio of normalized gene expressions using the Qgene software (Muller et al. 2002). The mean of cycle threshold values of four genes (smc02461, smc00568, smc01852, and smc00324) found to be substantially expressed at similar levels in a number of different conditions were used as reference for normalization.

\section{ACKNOWLEDGMENTS}

This work is dedicated to the memory of Frédéric Ampe. This work was supported by grants 0311752 and 031U213D from Bundesministerium für Forschung und Technologie, Germany and grant BIZ 7 from Deutsche Forschungsgemeinschaft, grants from the Toulouse Genopôle and the INRA Department 'Santé des Plantes et Environnement' (044104), and the CNRS programme "Puces à ADN". F. Ampe was supported by the Institut de Recherche pour le Développement (IRD) and E. Meilhoc by the Institut National des Sciences Appliquées (INSA). We thank E. Kiss for help in designing primers; C. Tonon for help in spotting PCR products on nylon membranes; E. Schulte-Berndt for help in PCR amplifications; A.-M. Garnerone for help in preparation and analysis of PCR products; and S. Carrère, E. Courcelle, C. Bru, D. Allouche, F. Meyer, B. Linke, M. Dondrup, and A. Goesmann for help with bioinformatics.

\section{LITERATURE CITED}

Ampe, F., Kiss, E., Sabourdy, F., and Batut, J. 2003. Transcriptome analysis of Sinorhizobium meliloti during symbiosis. Genome Biol. 4:R15.

Arslan, E., Kannt, A., Thony-Meyer, L., and Hennecke, H. 2000. The symbiotically essential cbb(3)-type oxidase of Bradyrhizobium japonicum is a proton pump. FEBS (Fed. Eur. Biochem. Soc.) Lett. 470:7-10.

Bardin, S., Dan, S., Osteras, M., and Finan, T. M. 1996. A phosphate transport system is required for symbiotic nitrogen fixation by Rhizobium meliloti. J. Bacteriol. 178:4540-4547.

Barnett, M. J., Fisher, R. F., Jones, T., Komp, C., Abola, A. P., BarloyHubler, F., Bowser, L., Capela, D., Galibert, F., Gouzy, J., Gurjal, M., Hong, A., Huizar, L., Hyman, R. W., Kahn, D., Kahn, M. L., Kalman, S., Keating, D. H., Palm, C., Peck, M. C., Surzycki, R., Wells, D. H., Yeh, K. C., Davis, R. W., Federspiel, N. A., and Long, S. R. 2001a. Nucleotide sequence and predicted functions of the entire Sinorhizobium meliloti pSymA megaplasmid. Proc. Natl. Acad. Sci. U.S.A. 98:98839888.

Barnett, M. J., Hung, D. Y., Reisenauer, A., Shapiro, L., and Long S. R. 2001b. A homolog of the CtrA cell cycle regulator is present and essential in Sinorhizobium meliloti. J. Bacteriol. 183:3204-3210.

Barnett, M. J., and Long, S. R. 1997. Identification and characterization of a gene on Rhizobium meliloti pSyma, $s y r B$, that negatively affects $s y r M$ expression. Mol. Plant-Microbe Interact. 10:550-559.

Batut, J., Daveran, M. M., David, M., Jacobs, J., Garnerone, A.-M., and Kahn, D. 1989. fixK, a gene homologous with fnr and crp from Escherichia coli, regulates nitrogen fixation genes both positively and negatively in Rhizobium meliloti. EMBO (Eur. Mol. Biol. Organ.) J. $8: 1279-1286$.

Becker, A., and de Bruijn, F. J. Transcriptomics in Sinorhizobium meliloti. In: Nitrogen Fixation: 1888-2001. Volume VI: Genomes and genomics of nitrogen-fixing organisms. R. Palacios and W. E. Newton, eds. Kluwer Academic Publishers, Dordrecht, The Netherlands. In press.

Bergès, H., Lauber, E., Liebe, C., Batut, J., Kahn, D., de Bruijn, F. J., and Ampe, F. 2003. Development of Sinorhizobium meliloti pilot macroarrays for transcriptome analysis. Appl. Environ. Microbiol. 69:12141219.

Beringer, J. E. 1974 R factor transfer in Rhizobium leguminosarum. J. Gen. Microbiol. 84:188-198.

Bertram-Drogatz, P. A., Quester, I., Becker, A., and Pühler, A. 1998. The Sinorhizobium meliloti MucR protein, which is essential for the production of high-molecular-weight succinoglycan exopolysaccharide, binds to short DNA regions upstream of exoH and exoY. Mol. Gen. Genet. 257:433-441.

Cabanes, D., Boistard, P., and Batut, J. 2000. Symbiotic induction of pyruvate dehydrogenase genes from Sinorhizobium meliloti. Mol. PlantMicrobe Interact. 13:483-493.

Campbell, G. R. O., Reuhs, B. L., and Walker G. C. 2002. Chronic intracellular infection of alfalfa nodules by Sinorhizobium meliloti requires correct lipopolysaccharide core. Proc. Natl. Acad. Sci. U.S.A. 99:39383943.

Capela, D., Barloy-Hubler, F., Gouzy, J., Bothe, G., Ampe, F., Batut, J., Boistard, P., Becker, A., Boutry, M., Cadieu, E., Dréano, S., Gloux, S., Godrie, T., Goffeau, A., Kahn, D., Kiss, E., Lelaure, V., Masuy, D., Pohl, T., Portetelle, D., Pühler, A., Purnelle, B., Ramsperger, U., Renard, C., Thébault, P., Vandenbol, M., Weidner, S., and Galibert, F. 2001. Analysis of the chromosome sequence of the legume symbiont Sinorhizobium meliloti. Proc. Natl. Acad. Sci. U.S.A. 98:9877-9882.

Chin, N., Frey, J., Chang, C. F., and Chang, Y. F. 1996. Identification of a locus involved in the utilization of iron by Actinobacillus pleuropneumoniae. FEMS (Fed. Eur. Microbiol. Soc.) Microbiol. Lett. 143:1-6.

Claverys, J. P. 2001. A new family of high affinity ABC manganese and zinc permeases. Res. Microbiol. 152:231-243. 
Cosseau, C., Garnerone, A.-M., and Batut, J. 2002. The fixM flavoprotein modulates inhibition by AICAR or 5'AMP of respiratory and nitrogen fixation gene expression in Sinorhizobium meliloti. Mol. Plant-Microbe Interact. 15:598-607.

Davey, M. E., and de Bruijn, F. J. 2000. A homologue of the tryptophanrich sensory protein $\mathrm{TspO}$ and FixL regulate a novel nutrient deprivation-induced Sinorhizobium meliloti locus. Appl. Environ. Microbiol. 66:5353-5359.

Day, D. A., Kaiser, B. N., Thomson, R., Udvardi, M. K., Moreau, S., and Puppo, A. 2001. Nutrient transport across symbiotic membranes from legume nodules. Aust. J. Plant Physiol. 28:667-674.

De Risi, J. L., Iyer, V. R., and Brown, P. O. 1997. Exploring the metabolic and genetic control of gene expression on a genomic scale. Science 278:680-686.

D'Hooghe, I., Vander Wauven, C., Michiels, J., Tricot, C., de Wilde, P., Vanderleyden, J., and Stalon, V. 1997. The arginine deiminase pathway in Rhizobium etli:DNA sequence analysis and functional study of the $\operatorname{arcABC}$ genes. J. Bacteriol. 179:7403-409.

Djordjevic, M. A., Chen, H. C., Natera, S., Van Noorden, G., Menzel, C., Taylor, S., Renard, C., Geiger, O., The Sinorhizobium meliloti Sequencing Consortium, and Weiller, G. F. 2003. A global analysis of protein expression profiles in Sinorhizobium meliloti: Discovery of new genes for nodule occupancy and stress adaptation. Mol. Plant-Microbe Interact. 16:508-524.

Dondrup, M., Goesmann, A., Bartels, D., Kalinowski, J., Krause, L., Linke, B., Rupp, O., Sczyrba, A., Pühler, A., and Meyer F. EMMA: A platform for consistent storage and efficient analysis of microarray data. J. Biotechnol. 106:135-146.

Driscoll, B. T., and Finan T. M. 1997. Properties of NAD ${ }^{+}-$and NADP ${ }^{+}$ dependent malic enzymes of Rhizobium (Sinorhizobium) meliloti and differential expression of their genes in nitrogen fixing bacteroids. Microbiology 143:489-498.

Dudoit, S., Yang, Y. H., Callow, M. J., and Speed T. P. 2002. Statistical methods for identifying differentially expressed genes in replicated cDNA microarray experiments. Stat. Sin. 12:111-139.

Finan, T. M., Weidner, S., Chain, P., Buhrmester, J., Wong, K., Vorhölter, F.-J., Hernandez-Lucas, I., Becker, A., Cowie, A., Gouzy, J., Golding, B., and Pühler, A. 2001. The complete sequence of the 1,683-kb pSymB megaplasmid from the $\mathrm{N}_{2}$-fixing endosymbiont Sinorhizobium meliloti. Proc. Natl. Acad. Sci. U.S.A. 98:9889-9894.

Galibert, F., Finan, T. M., Long, S. R., Pühler, A., Abola, P., Ampe, F., Barloy-Hubler, F., Barnett, M. J., Becker, A., Boistard, P., Bothe, G., Boutry, M., Bowser, L., Buhrmester, J., Cadieu, E., Capela, D., Chain, P., Cowie, A., Davis, R. W., Dréano, S., Federspiel, N. A., Fisher, R. E. Gloux, S., Godrie, T., Goffeau, A., Golding, B., Gouzy, J., Gurjal, M. Hernandez-Lucas, I., Hong, A., Huizar, L., Hyman, R. W., Jones, T., Kahn, D., Kahn, M. L., Kalman, S., Keating, D., Kiss, E., Komp, C., Lelaure, V., Masuy, D., Palm, C., Peck, M. C., Pohl, T., Portetelle, D., Purnelle, B., Ramsperger, U., Surzycki, R., Thébault, P., Vandenbol, M., Vorhölter, F.-J., Weidner, S., Wells, D. H., Wong, K., Yeh, K.-C., and Batut, J. 2001. The composite genome of the legume symbiont $\mathrm{Si}$ norhizobium meliloti. Science 293:668-672.

Gallusci, P., Dedieu, A., Journet, E. P., Huguet, T., and Barker, D. G. 1991 Synchronous expression of leghaemoglobin genes in Medicago truncatula during nitrogen-fixing root nodule development and response to exogenously supplied nitrate. Plant Mol. Biol. 17:335-349.

González, J. E., Semino, C. E., Wang, L., Castellano-Torres, L. E., and Walker, G. C. 1998. Biosynthetic control of molecular weight in the polymerization of the octasaccharide subunits of succinoglycan, a symbiotically important exopolysaccharide of Rhizobium meliloti. Proc. Natl. Acad. Sci. U.S.A. 95:13477-13482.

Green, L. S, Li, Y. Z., Emerich, D. W., Bergersen, F. J., and Day, D. A. 2000. Catabolism of alpha ketoglutarate by a sucA mutant of Bradyrhizobium japonicum:evidence for an alternative tricarboxylic acid cycle. J. Bacteriol. 182:2838-2844.

Hérouart, D., Sigaud, S., Moreau, S., Frendo, P., Touati, D., and Puppo, A. 1996. Cloning and characterization of the katA gene of Rhizobium meliloti encoding a hydrogen peroxide-inducible catalase. J. Bacteriol. 178:6802-6809.

Jamet, A., Sigaud, S., Van de Sype, G., Puppo, A., and Hérouart, D. 2003. Expression of the bacterial catalase genes during Sinorhizobium meliloti-Medicago sativa symbiosis and their crucial role during the infection process. Mol. Plant-Microbe Interact. 16:217-225.

Jiménez-Zurdo, J. I., Vandillewijn, P., Soto, M. J., Defelipe, M. R., Olivares, J., and Toro, N. 1995. Characterization of a Rhizobium meliloti proline dehydrogenase mutant altered in nodulation efficiency and competitiveness on alfalfa roots. Mol. Plant-Microbe Interact. 8:492-498.

Kanipes, M. I., Kalb, S. R., Cotter, R. J., Hozbor, D. F., Lagares, A., and Raetz, R. H. 2003. Relaxed sugar donor selectivity of a Sinorhizobium meliloti ortholog of the Rhizobium leguminosarum mannosyl transferase LpcC. J. Biol. Chem. 278:16365-16371.

Kannenberg, E. L., Reuhs, B. L., Forsberg, S., and Carlos, R. W. 1998. Lipopolysaccharides and K-antigens: Their structures, biosynthesis, and functions. Pages 119-154 in: The Rhizobiaceae. H. P. Spaink, A. Kondorosi, and P. J. J. Hooykaas, eds. Kluwer Academic Publishers, Dordrecht, The Netherlands.

Kereszt, A., Kiss, E., Reuhs, B. L., Carlson, R. W., Kondorosi, A., and Putnoky, P. 1998. Novel rkp gene clusters of Sinorhizobium meliloti involved in capsular polysaccharide production and invasion of the symbiotic nodule: The $r k p K$ gene encodes a UDP-glucose dehydrogenase. J. Bacteriol. 180:5426-5431.

Kereszt, A., Slaska-Kiss, K., Putnoky, P., Banfalvi, Z., and Kondorosi, A 1995. The cycHJKL genes of Rhizobium meliloti involved in cytochrome c biogenesis are required for "respiratory" nitrate reduction ex planta and for nitrogen fixation during symbiosis. Mol. Gen. Genet. 247:39-47.

Layzell, D. B., Hunt, S., and Palmer, G. R. 1990. Mechanism of nitrogenase inhibition in soybean nodules. Plant Physiol. 92:1101-1107.

Lockhard, D. J., and Winzeler, E. A. 2000. Genomics, gene expression and DNA arrays. Nature 405:827-836.

Lodwig, E., and Poole, P. 2003. Metabolism of Rhizobium bacteroids. Crit. Rev. Plant Sci. 22:37-78.

Lodwig, E. M., Hosie, A. H. F., Bourdès, A., Findlay, K., Allaway, D., Karunakaran, R., Downie, J. A., and Poole, P. S. 2003. Amino-acid cycling drives nitrogen fixation in the legume-Rhizobium symbiosis. Nature 422:722-726

Long, S. 2001. Genes and signals in the Rhizobium-legume symbiosis. Plant Physiol. 125:69-72.

Luthi, E., Mercenier, A., and Haas, D. 1986. The $\operatorname{arcABC}$ operon required for fermentative growth of Pseudomonas aeruginosa on arginine:Tn5751 -assisted cloning and localization of structural genes. J. Gen. Microbiol. 132:2667-2675.

Lynch, D., O’Brian, J., Welch, T., Clarke, P., Cuív, P. Ó., Crosa, J. H., and O'Connell, M. 2001. Genetic organization of the region encoding regulation, biosynthesis, and transport of rhizobactin 1021, a siderophore produced by Sinorhizobium meliloti. J. Bacteriol. 183:2576-2585

Meade, H. M., and Signer, E. R. 1977. Genetic mapping of Rhizobium meliloti. Proc. Natl. Acad. Sci. U.S.A. 74:2076-2078.

Muller, P. Y., Janovjak, H., Miserez, A. R., and Dobbie, Z. 2002. Processing of gene expression data generated by quantitative real-time RTPCR. Biotechniques 32:1372-1378.

Mulligan, J. T., and Long, S. R. 1989. A family of activator genes regulates expression of Rhizobium meliloti nodulation genes. Genetics 122:7-18

Natera, S. H. A., Guerreiro, N., and Djordjevic, M. A. 2000. Proteome analysis of differentially displayed proteins as a tool for the investigation of symbiosis. Mol. Plant-Microbe Interact. 13:995-1009.

Niehaus, K., and Becker, A. 1998. The role of microbial surface polysaccharides in the Rhizobium legume interaction. Pages 73-115 in: Subcellular Biochemistry. Plant-Microbe Interactions Vol. 29. B. B. Biswas and H. K. Das, eds. Plenum Press, New York.

Niehaus, K., Lagares, A., and Pühler, A. 1998. A Sinorhizobium meliloti lipopolysaccharide mutant induces effective nodules on the host plant Medicago sativa (alfalfa) but fails to establish a symbiosis with Medicago truncatula. Mol. Plant-Microbe Interact. 11:906-914.

O'Hara, G. W., Daniel, R. M., and Steele, K. W. 1983 Effect of oxygen on the synthesis, activity and breakdown of the Rhizobium denitrification system. J. Gen. Microbiol. 129:2405-2412.

Oke, V., and Long, S. R. 1999a. Bacterial genes induced within the nodule during the Rhizobium-legume symbiosis. Mol. Microbiol. 32:837-850.

Oke, V., and Long, S. R. 1999b. Bacteroid formation in the Rhizobiumlegume symbiosis. Curr. Opin. Microbiol. 2:641-646.

Paau, A. S., Bloch, C. B., and Brill, W. J. 1980. Developmental fate of Rhizobium meliloti bacteroids in alfalfa nodules. J. Bacteriol. 143:14801490.

Pellock, B. J., Cheng, H.-P., and Walker, G. C. 2000. Alfalfa root nodule invasion efficiency is dependent on Sinorhizobium meliloti polysaccharides. J. Bacteriol. 182:4310-4318.

Perret, X., Freiberg, C., Rosenthal, A., Broughton, W. J., and Fellay, R. 1999. High-resolution transcriptional analysis of the symbiotic plasmid of Rhizobium sp. NGR234. Mol. Microbiol. 32:415-425.

Platero, R. A., Jaureguy, M., Battistoni, F. J., and Fabiano, E. R. 2003. Mutations in sitB and sitD genes affect manganese-growth requirements in Sinorhizobium meliloti. FEMS Microbiol. Lett. 218:65-70.

Renalier, M. H., Batut, J., Ghai, J., Terzaghi, B., Ghérardi, M., David, M., Garnerone, A.-M., Vasse, J., Truchet, G., Huguet, T., and Boistard, P. 1987. A new symbiotic cluster on the pSym megaplasmid of Rhizobium meliloti 2011 carries a functional fix gene repeat and a nod locus. J. Bacteriol. 169:2231-2238. 
Reuber, T. L., Long, S., and Walker, G. C. 1991. Regulation of Rhizobium meliloti exo genes in free-living cells and in planta by using TnphoA fusions. J. Bacteriol. 173:426-434.

Rhodius, V., Van Dyk, T. K., Gross, C., and LaRossa, R. A. 2002. Impact of genomic technologies on studies of bacterial gene expression. Annu. Rev. Microbiol. 56:599-624.

Roest, H. P., Goosen-de Roo, L., Wijffelman, C. A., de Maagd, R. A., and Lugtenberg, B. J. J. 1995. Outer membrane protein changes during bacteroid development are independent of nitrogen fixation and differ between indeterminate and determinate nodulating host plants of Rhizobium leguminosarum. Mol. Plant-Microbe Interact. 8:14-22.

Rossbach, S., Loferer, H., Acuna, G., Appleby, C. A., and Hennecke, H. 1991. Cloning, sequencing and mutational analysis of the cytochrome c552 gene $($ cycB) from Bradyrhizobium japonicum strain 110. FEMS (Fed. Eur. Microbiol. Soc.) Microbiol. Lett. 67:145-152.

Rüberg, S., Tian, Z.-X., Krol, E., Linke, B., Meyer, F., Wang, Y., Pühler, A., Weidner, S., and Becker, A. Construction and validation of a Sinorhizobium meliloti whole genome DNA microarray:genome-wide profiling of osmoadaptive gene expression. J. Biotechnol. 106:255-268.

Santos, R., Hérouart, D., Puppo, A., and Touati, D. 2000. Critical protective role of bacterial superoxide dismutase in Rhizobium-legume symbiosis. Mol. Microbiol. 38:750-759.

Sharma, S. B., and Signer, E. R. 1990. Temporal and spatial regulation of the symbiotic genes of Rhizobium meliloti in planta revealed by transposon Tn5-gusA. Genes Dev. 4:344-356.

Sharypova, L. A., Yurgel, S. N., Keller, M., Simarov, B. V., Pühler, A., and Becker, A. 1999. The eff-482 locus of Sinorhizobium meliloti CXM1105 that influences symbiotic effectiveness consists of three genes encoding an endoglycanase, a transcriptional regulator and an adenylate cyclase. Mol. Gen. Genet. 261:1032-1044.

Soupène, E., Foussard, M., Boistard, P., Truchet, G., and Batut, J. 1995. Oxygen as a key developmental regulator of Rhizobium meliloti $\mathrm{N}_{2^{-}}$ fixation gene expression within the alfalfa root nodule. Proc. Natl. Acad. Sci. U.S.A. 92:3759-3763.

Sourjik, V., Sterr, W., Platzer, J., Bos, I., Haslbeck, M., and Schmitt, R. 1998. Mapping of 41 chemotaxis, flagellar and motility genes to a single region of the Sinorhizobium meliloti chromosome. Gene 1998 223:283-90.

Spaink, H. P. 2000. Root nodulation and infection factors produced by rhizobial bacteria. Annu. Rev. Microbiol. 54:559-582.

Vasse, J., de Billy, F., Camut, S., and Truchet, G. 1990. Correlation between ultrastructural differentiation of bacteroids and nitrogen fixation in alfalfa nodules. J. Bacteriol. 172:4295-4306.

Vincent, J. M. 1970. A Manual for the Practical Study of Root Nodule Bacteria. IBP Handbook No. 15. Blackwell Scientific Publications, Oxford.

Werner, D., and Mörschel, E. 1978. Differentiation of nodules of Glycine max:ultrastructural studies of plant cells and bacteroids. Planta 141:169-177.

Yang, Y. H., Dudoit, S., Luu, P., Lin, D. M., Peng, V., Ngai, J., and Speed, T. P. 2002. Normalization for cDNA microarray data: A robust composite method addressing single and multiple slide systematic variation. Nucleic Acids Res. 30:e15.

\section{AUTHOR-RECOMMENDED INTERNET RESOURCES}

The Bielefeld University Bioinformatics Resource Facility EST and microarray database: genetik.uni-bielefeld.de/EMMA/

Full hybridization data sets of this study: Genetik.Uni-Bielefeld.DE/ abecker/

INRA Sinorhizobium meliloti 1021 Genome Project webpage: sequence. toulouse.inra.fr/meliloti.html

Microarrays.org protocol webpage: microarrays.org/protocols.html 